\title{
COVID-19 y los desafíos que plantea a la humanidad
}

\section{COVID-19 and the challenges it poses to humanity}

\author{
Aldo Vivar-Mendoza'
}

Las imágenes del mundo actual parecían salir de una película de ciencia ficción: calles vacías, fronteras cerradas, escasa circulación por los espacios aéreos o marítimos, salvo viajes esenciales. La supuesta superioridad tecnológica humana fue vapuleada por un simple agente natural y prácticamente ha puesto al mundo en cuarentena, el SARS CoV-2. El mundo se detuvo y con ello la naturaleza se dio literalmente un respiro, los indicadores de contaminación ambiental disminuyeron considerablemente.

El SARS CoV-2, conocido también como coronavirus o por la enfermedad que produce (COVID-19), es un virus de la familia Corona, llamada así por las espículas que sobresalen de la cubierta viral proteica. Estos virus circulan entre especies animales e incidentalmente "saltan" a humanos, en un efecto llamado spillover (derramamiento). Al momento se conocen siete coronavirus capaces de infectar al ser humano, cuatro de ellos provocan el resfrío común y los últimos tres están ligados a epidemias muy virulentas, el SARS (Severe Acute Respiratory Syndrome), aparecido en 2002 y desaparecido en 2004, el MERS (Middle East Respiratory Syndrome), aparecido en 2014 y aun circulando en camélidos, y, el SARS CoV-2, del que se estima que entre finales de noviembre e inicios de diciembre dio un salto cualitativo, un spillover, desde especies animales hacia humanos. Se especula que el comercio ilegal de animales, en este caso el pangolín malayo -un animal cuyo contrabando es motivado por supuestas propiedades medicinales- y la interacción con especies de murciélagos. La historia del SARS CoV-2 es la misma vivida con otros virus que saltaron a otras especies, el VIH desde los monos, el Ébola desde murciélagos, el Nipah proveniente de cerdos y el virus de la influenza desde las aves. La naturaleza es un gran laboratorio donde las mutaciones virales y su salto a otras especies animales proveen de hospederos potenciales, esto sumado a la expansión de las fronteras urbanas sobre espacios silvestres que expone a los humanos a nuevos gérmenes.

Médico internista. Facultad de Medicina, Universidad Peruana cayetano Heredia. Hospital Nacional Arzobispo Loayza, Perú.
Vivar-Mendoza A. COVID- 19 y los desafíos que plantea a la humanidad Rev Soc Peru Med Interna. 2019;33(3):98-100.

https://doi.org/10.36393/spmi.v33i3.545

Los primeros casos de enfermedad por SARS CoV-2 se reportaron en un mercado de la comunidad de Wuhan en China, a mediados de diciembre del 2019 y durante enero del 2020 se diseminó rápidamente desde aquella región sur al resto del país y luego a otras regiones de Asia. Aprovechando de un mundo conectado en cuestión de horas por los viajes internacionales, el virus alcanzó los cinco continentes utilizando a seres humanos como medio de transporte y por la facilidad del contagio respiratorio, el virus ha atravesado miles de kilómetros para convertirse en una amenaza en cada país que ha llegado aprovechando la manera de cómo se ha diseñado la vida actual: un comercio y transporte globalizados, grandes ciudades, transporte urbano masivo y un progresivo desmantelamiento del sistema de soporte social a favor de un individualismo a ultranza. De modo invisible pero no menos efectivo, el sistema ha despojado a cierta parte de la humanidad de valores éticos como la solidaridad y la equidad así como el sentido de colectividad. La llegada de este virus ha puesto en cuestionamiento sistemas y valores con unas consecuencias que aún son imposibles de valorar. Como toda epidemia, todas las brechas han quedado expuestas.

El 20 de enero del 2020 se reportaron los primeros casos fuera de China continental en Japón, Corea del Sur y Tailandia. El 30 de ese mes, ante la magnitud de la epidemia (10 000 casos en China y una extensión de la epidemia en 22 países) la OMS declaró la existencia de una emergencia sanitaria global, ese mismo día recomendó el uso de mascarillas tanto en ambientes sanitarios como en los domésticos. Al día siguiente, la administración Trump prohibió el ingreso a territorio estadounidense de extranjeros provenientes de China, un país con el que el tráfico de pasajeros era muy alto; así, el promedio de visitantes fue de 19000 por día durante el 2019

El 11 de febrero la OMS le confirió a la enfermedad su actual nombre, COVID-19 (Coronavirus disease 2019), para entonces China tenía 44653 infectados y 1113 fallecidos, la enfermedad ya se había esparcido a 24 países en diversos continentes.

La migración humana hacía lo suyo. Millones de peregrinos y trabajadores migrantes del mundo islámico visitaron Irán, 
dejando una estela de infecciones y muertes, para entonces se convirtió, luego de China, en el segundo país con más infecciones.

El primer caso en América Latina se reportó en Brasil el 26 de febrero, en Perú se hizo lo propio el 6 de marzo. El virus llegó desde Europa que para entonces era el epicentro de la epidemia. El 11 de marzo, la OMS declaró al COVID-19 como una pandemia, varios países comenzaron a cerrar sus fronteras y su espacio aéreo. Los países más golpeados en Europa fueron España, Italia y el Reino Unido. Con el paso de los meses América se convirtió en el nuevo epicentro. Al 17 de agosto se han reportado globalmente 21 549,706 casos, los seis países con más casos son EEUU (5 312 940), Brasil (3 317 906), India (2 647 633), Rusia (927, 745), Sudáfrica (587 345) y Perú (525 803).

Algo salió mal desde que Perú implementó una cuarentena obligatoria a mediados de marzo. Las explicaciones pueden ser varias, entre ellas el repliegue de las actividades sanitarias a los grandes hospitales COVID descuidando el primer nivel de atención, que si bien no tenía tratamientos que ofrecer hubiese trabajado mejor la vigilancia epidemiológica y reforzado el aislamiento de casos. Pero, ante una nueva enfermedad y las pocas evidencias, eso es algo que no se vislumbró en su real magnitud en su momento. Por otro lado, a la población le ha costado y le cuesta acatar el orden. Cada semana se vio un endurecimiento progresivo de las normas de confinamiento como una nueva vuelta de tuerca que ajuste el desorden.

Pero el desorden apareció por el lado menos esperado, al parecer la población entendió que las primeras dos semanas eran suficientes para "aplanar la curva", no fue así y la cuarentena se fue alargando. Cansados de esperar y sin trabajo muchos ciudadanos originarios de las provincias del interior decidieron volver a su terruño a pie ante los desafíos de una ciudad que no les ofrecía ningún beneficio, ocurriendo la migración inversa. Además, los mercados se convirtieron en centros de aglomeración y muchas personas incumplieron las normas de distanciamiento social, la consecuencia: casi la mitad de los comerciantes se infectaron. Mayo y junio fueron meses de crecimiento sostenido de casos, como resultado de ello los grandes hospitales colapsaron y el sistema sanitario emprendió una apertura de más camas hospitalarias y una expansión de las unidades de cuidados intensivos.

En vista que la economía doméstica cada vez ajustaba más a los ciudadanos, especialmente toda aquella economía informal que vive al día y con una proporción significativa de hogares que no cuentan con refrigeradoras para almacenar alimentos por largo tiempo. La población poco a poco comenzó a salir a la calle ante un progresivo relajamiento de la vigilancia policial hasta que, finalmente, en el mes de julio se retiró la cuarentena, aunque conservaba el toque de queda.

La disyuntiva entre la economía y la salud se resolvió por la primera, lo que ha devuelto a la población a las condiciones de vida pre pandemia. Con ello, se esperaba un rebrote de casos -como la experiencia en otros países lo está demostrando- lo que finalmente ocurrió. La apertura de carreteras y con ello los viajes interprovinciales germinaron un nuevo problema: la exportación de casos desde Lima, el epicentro de la epidemia, a las regiones, que poseen sistemas sanitarios de menores recursos y en la mayoría de casos autoridades locales con una muy pobre capacidad de gestión.

El retiro de la cuarentena tuvo también consecuencias en el comportamiento de la población, en parte por el hastío del encierro y en parte por una falsa sensación de seguridad, la movilización urbana de la población aumentó, como consecuencia de ello aumentó la transmisión intradomiciliaria y se han visto familias internadas al mismo tiempo en los grandes hospitales de Lima.

Esta pandemia ha generado consecuencias económicas significativas y varios países ven la recesión económica como una realidad. El cierre de fronteras continúa y en Europa donde se permitieron los desplazamientos entre países comunitarios se está viendo la imposición de cuarentenas a los viajeros.

Por el lado la ciencia, lo que se ha visto es una enorme capacidad para el desarrollo de tecnologías y sobre todo el compartir información, se ha mapeado el genoma viral, se conoce más de los mecanismos de transmisión, del curso clínico, de la significativa tasa de asintomáticos y así también la capacidad del virus de provocar manifestaciones extrapulmonares y lamentablemente secuelas que por la juventud de la pandemia no podemos valorar sino cuando pase más tiempo. Los medicamentos utilizados han tenido un auge y caída: hidroxicloroquina, azitromicina, lopinavir/ritonavir, tocilizumab no lograron desenlaces clínicos significativos de beneficio. A casi seis meses de ensayos clínicos solo dexametasona, a través del estudio RECOVERY, ha demostrado una significativa disminución de la mortalidad en los casos moderados a severos. Por supuesto, no se discute el valor del oxígeno suplementario y la ventilación asistida en la supervivencia de casos de COVID-19, planteando dilemas morales sobre la prioridad de ingreso a unidades de cuidados intensivos ante la escasez de camas. Preocupa, además, la elevada mortalidad en las personas obesas.

Los ojos del mundo, entonces, han virado con esperanza hacia el desarrollo de vacunas, de casi 200 prototipos una decena de ellas están pasando de la fase I a la II y se avizora que unas cinco deben ingresar a fase III desde setiembre. Los modelos van de virus inactivados, porciones de ARN, componentes virales insertados en un adenovirus. La comunidad científica trabaja a velocidad y se han hecho convenios entre universidades y compañías farmacéuticas para asegurar la demanda. En forma paralela, los gobiernos trabajan para ser los primeros en la lista de receptores y de declarar la vacuna como un bien común de la humanidad para asegurar su acceso.

Pareciera que las primeras dos décadas de cada siglo fueran un punto de inflexión, en el XIX las guerras de la independencia americana, en el XX la Gran Guerra y la 
epidemia de influenza. El siglo XXI ha traído un virus que ha provocado el repliegue de la humanidad y ha puesto en cuestión un modelo económico, social y político. El mundo está con turbulencia y las respuestas son dispares, de la sensatez a la intolerancia, de las medidas sensatas y basadas en la ciencia a las que están basadas en el fanatismo y las creencias atávicas.

En épocas de crisis se ven todos los ángulos, dobleces y destellos de la naturaleza humana. Cada ciudadano, cada institución y, por ende, cada sociedad científica o académica debe colocarse a la altura de su historia y circunstancias. En nuestro caso la ciencia es el espacio de escrutinio y debate, de confrontación de hechos, sin dejar de lado nuestra condición de humanos, en el sentido moral del término, de la convivencia en colectividad, de la empatía y misericordia, del respeto y del pensar en el otro, solo así la humanidad ha pervivido como especie.
A nuestra generación nos ha tocado vivir este momento, es hora de hacer de las buenas intenciones un compromiso a largo plazo, estamos escribiendo la historia que nuestros descendientes leerán mañana.

\section{REFERENCIA BIBLIOGRAFÍA}

1. La literatura sobre COVID-19 es copiosa y de acceso libre. El autor ha revisado los sitios web de The Lancet, New England Journal of Medicine, JAMA, Annals of Internal Medicine, Nature, Science, Cell, PNAS, National Institutes of Health, Centers for Disease Control, World Health Organization, Ministerio de Salud del Perú, Imperial College, John Hopkins University, así como múltiples portales web de los principales diarios del Perú y el mundo, así como de periodismo independiente.

\section{CORRESPONDENCIA:}

Aldo Vivar-Mendoza

aldo.vivar.m@upch.pe

Fecha de recepción: 17-08-2020.

Fecha de aceptación: 24-08-2020. 